\title{
The defensive behavioral patterns of captive white-lipped and collared peccary (Mammalia, Tayassuidae): an approach for conservation of the species
}

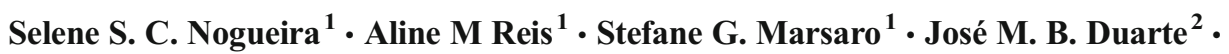 \\ Viviana Moreto $^{1} \cdot$ Stella G. C. Lima ${ }^{1} \cdot$ Thaise S. O. Costa $^{1} \cdot$ Sérgio L G Nogueira-Filho ${ }^{1}$
}

Received: 11 February 2016 /Revised: 1 February 2017 / Accepted: 6 February 2017 / Published online: 15 February 2017

(C) Springer-Verlag Berlin Heidelberg and ISPA 2017

\begin{abstract}
Defensive behavioral patterns in response to human-induced rapid environmental change can affect animals' fitness and may play a role in species conservation status. To test this hypothesis, we compared the risk assessment and defensive behavioral responses of captive white-lipped peccary (WLP; Tayassu pecari) and collared peccary (CP; Pecari tajacu), which retain different conservation status; WLP are considered vulnerable and CP of least concern. We used an adapted paradigm of the mouse defense test battery (MDTB) comprising four consecutive tests. Two of these tests simulated a novel environment, while the other two stimulated the expression of defensive behavioral patterns. Besides differences in risk assessment and defensive threat/attack behavioral patterns between species, we compared flight initiation distance, flight speed, and plasma glucocorticoid concentrations. When facing a novel environment and risk challenges from humans' predator-like cues, the white-lipped peccary showed more exploratory and defensive threat/attack behavioral patterns, shorter flight initiation distances, and lower flight speeds, whereas the collared peccaries showed more cautious and retreat patterns, longer flight initiation distances, and higher flight speeds. There were also correlations between physiological and behavioral parameters. We confirmed our hypothesis that the collared peccary's cautiousness may help to prevent a decrease in its population, while the white-lipped
\end{abstract}

Selene S. C. Nogueira

seleneuesc@gmail.com

1 Applied Ethology Laboratory, Universidade Estadual de Santa Cruz, Rodovia Jorge Amado Km 16, Ilhéus, BA 45662-900, Brazil

2 São Paulo State University/Jaboticabal Campus, Rodovia de Acesso Prof. Paulo Donato Castellane s/n, Jaboticabal, SP 14884-900, Brazil peccary's exploratory and confrontational behavioral patterns in overhunted areas, together with other simultaneous factors as forest fragmentation, might contribute to placing this species in the vulnerable category.

Keywords Behavioral plasticity · Defensive strategy · HIREC $\cdot$ Intra-specific variation $\cdot$ Risk assessment

\section{Introduction}

Vertebrates show defensive behavior or risk assessment patterns when exposed to threatening situations (Blanchard et al. 2001). These behaviors mainly occur when the animals detect indirect and direct cues for predation risk (Dielemberg and Mcgregor 2001; Kavaliers and Choleris 2001; Orrock et al. 2004; Schmidt 2006; Nersesian et al. 2012). The most frequent defensive patterns in vertebrates are flight, freezing, and defensive threat or attack (Blanchard and Blanchard 1988). The choice among defensive patterns depends on the prey's capabilities, strategies to deal with predators, and the degree of predation risk in a new environment (Lima and Dill 1990). However, an invariable behavior between prey/predator relationships may result in more vulnerable strategies (Luttbeg and Sih 2010), which may increase the risk to the species (Wolf et al. 2007).

Besides natural events, such as predator attacks, humaninduced rapid environmental change (HIREC) (sensu Sih 2013) has challenged organisms to cope with forest fragmentation, translocation, climate change, and harvesting by humans (Herborn et al. 2014). Behavioral or phenotypic plasticity (Sih 2013; Mason et al. 2013) have been suggested as aspects that are more responsible for coping with HIREC than is genetic evolution (Charmantier et al. 2008; van Buskirk 2012; Sih 2013). Baldwin (1896) was the first author to 
comment on behavioral plasticity as one of the main mechanisms that promote population persistence in a changing environment. In response to such changes, many populations or species adapt or even thrive, while others move, decline, or even become extinct according to their behavioral plasticity (Price et al. 2003; Sih et al. 2011).

The white-lipped peccary (Tayassu pecari) and the collared peccary (Pecari tajacu) are sympatric species with distinct conservation status (Gongora et al. 2011; Taber et al. 2011; Keuroghlian et al. 2013). Besides unsustainable levels of subsistence hunting (Cullen et al. 2001; Peres 2001; Gongora et al. 2011; Keuroghlian et al. 2013; Taber et al. 2016), both species face the negative effects of forest fragmentation caused by agriculture and human settlement (Beck et al. 2010; Licona et al. 2011; Taber et al. 2011). Nevertheless, the white-lipped peccary seems to be more susceptible to HIREC and was recently classified as a vulnerable species by the International Union for Conservation of Nature (IUCN) (Keuroghlian et al. 2013). In contrast, the collared peccary is more resilient and apparently copes very well with changing environmental challenges, and it is classified as being a species of least concern (Gongora et al. 2011). The extinction of these species is of particular concern because it could affect the spatial-temporal dispersion of animals and plants, which can result in changes in the tropical ecosystem and in reduced diversity (Ticktin 2003; Desbiez et al. 2009; Beck et al. 2010; Keuroghlian et al. 2013).

The literature survey on the defense strategies of these species is scarce; however, some anecdotal reports (Kiltie and Terborgh 1983; Sowls 1997) and an observational study (Nogueira et al. 2015) point out some differences between these two species. Living in large groups, which can reach over 400 individuals (Taber et al. 2011), enables whitelipped peccary collectively to counterattack against predators such as jaguar (Panthera onca) and puma (Felis concolor) (Kiltie and Terborgh 1983; Sowls 1997; Taber et al. 2011). This mass attack behavior, however, has been shown to be an inappropriate strategy against hunters (Sowls 1997). There are some reports that, when living in large groups, many white-lipped peccaries can be killed during a single hunting expedition due to their close herding tendencies (Sowls 1997; Cabassu 2010). The collared peccary, in contrast, usually lives in groups of 10 animals (Taber et al. 2011; Taber et al. 2016). Despite there are reports that they can also counterattacks against coyotes (Canis latrans) and pumas (Sowls 1997), collared peccaries often adopt flight as an anti-predatory strategy when threatened. The alertness of the collared peccary allows only one or two individuals to be killed per hunt (Sowls 1997). It can be inferred that hormonal responsiveness to novel stimuli or situations may trigger behavioral reactions in peccaries and may play an important role in population-level adaptation to HIREC (Sih 2013).
Mason et al. (2013) suggested the use of captive wild animals as a model to understand the impacts of HIREC at the individual level. The authors justified this approach arguing that successful captive animals maintained close to humans and submitted to threat stimuli similar to HIREC need to show behavioral plasticity. Therefore, we evaluated the use of the mouse defense test battery (MDTB) paradigm (Blanchard et al. 2003), adapted in size, to describe the risk assessment and defensive behavior patterns of white-lipped and collared peccaries. This paradigm enhances the animal's defensive responses by exposing it to threatening situations usually experienced by free-ranging animals, such as the assessment of a novel environment and humans' predator-like cues, and can yield new insights into how both species respond to HIREC. There are some reports showing that animals interrupt foraging and other essential behaviors due to excessive stimuli perceived as threatening, by means of accentuated endocrine stress responses (Beckerman et al. 2007; Mason 2010; Cockrem 2013; Wingfield 2013). Thus, we also analyzed the peccaries' glucocorticoid plasma concentration, both preand post-defense test battery, to investigate the influence of the experimental tests on the release of these stress hormones and the effects of this release on behavior.

\section{Materials and methods}

\section{Ethical note}

This work followed the "Principles of laboratory animal care" (NIH publication no. 86-23, revised 1985) and was approved by the Committee of Ethics for Animal Use, Universidade Estadual de Santa Cruz (proclamation no. 012/11).

\section{Animals and facilities}

The study was carried out at the Applied Ethology Laboratory, Universidade Estadual de Santa Cruz, Ilhéus, Bahia, Brazil $\left(14^{\circ} 47^{\prime} 39.8^{\prime \prime} \mathrm{S}, 39^{\circ} 10^{\prime} 27.7^{\prime \prime} \mathrm{W}\right)$. We used 10 adult collared peccaries $(23.1 \pm 3.8 \mathrm{~kg}), 5$ males and 5 females, and 10 adult white-lipped peccaries $(36.2 \pm 5.4 \mathrm{~kg}), 5$ males and 5 females, born and raised under captive conditions. The animals had never experienced true predation, despite humans' predatorlike cues (sensu Mason et al. 2013) when they were caught for weighing and veterinary evaluation every 3 months. During this process, they were captured and handled with a capture net after a short chase by two or three keepers. Thus, we chose the capture net to stimulate the expression of defensive behavioral patterns, such as tooth clicking, and animals even attacked the net and/or keepers, while being chased with the net (Nogueira-Filho, personal observation).

To evaluate animals' defensive behavior, we built a test arena in a corridor shape, measuring $15.0 \mathrm{~m}$ in length and 
$4.0 \mathrm{~m}$ in width, surrounded by a chain-link fence $1.5 \mathrm{~m}$ high. At the center of this enclosure, we built a chain-link wall $1.5 \mathrm{~m}$ high, dividing the test arena into two parallel corridors measuring $2.0 \mathrm{~m}$ in width each. At the end of both sides of this middle wall, there was a clearance, $1.0 \mathrm{~m}$ wide, which allowed the animals to move throughout the entire arena, unless the guillotine doors were closed to block the animals' passage when conducting one of the tests (chase plus forced contact test, described below). A black polyurethane sheet was fixed to the wire-mesh fence and central wall to avoid visual contact with the outside environment and between corridors during the tests. We placed a digital camcorder (JVC, model GZHD500; Tokyo, Japan) on a tripod $1.6 \mathrm{~m}$ high above one extremity of the test arena to record the animals' behavior continuously during all four tests.

\section{Test procedures}

Each animal was submitted to a battery of four consecutive tests: (a) novel environment, (b) chase, (c) forced contact, and (d) foraging/eating in a novel environment, to assess their defensive behavior following the MDTB methodology modified from Blanchard et al. (2003) and Ribeiro-Barbosa et al. (2005). The data collection occurred over 3 months, always in the morning between 0830 and $1000 \mathrm{~h}$, corresponding to the peak of animal's activity (Sowls 1997) and consequently the peak of collared and white-lipped peccaries' adrenal activity (Coradello et al. 2012; Nogueira-Filho et al. 2012). Each animal went through the four tests consecutively on the same day, without intervals between them. The battery of tests occurred with 2 days of intervals between individuals, alternating the species each time. The animals were chosen randomly in their paddocks, and they were individually caught with the capture net used to handle peccaries at this facility. We used the capture net to stimulate the expression of defensive behavioral patterns facing humans' predator-like cues in two of the tests (chase and forced contact tests; details below). When restrained inside the net, we collected the first blood sample (details below) to determine the pre-test levels of plasma glucocorticoid concentration. After blood collection, the subject was introduced into the test arena to undergo the defense test battery, described as follows:

Novel environment test: the animal was individually introduced into the test arena and remained free to explore the test arena environment for a period of $20 \mathrm{~min}$.

Chase test: the capture net, used to handle peccaries, was placed inside the arena, moving at a speed of $3 \mathrm{~m} / \mathrm{s}$. During the entire test, the animal could not see the net handler, who was outside the enclosure with the plastic sheet covering his body and head. The handler placed the net at the opposite side from where the animal was, and the chase began when the individual's head was oriented in the direction of the capture net. The chase finished after the net came close up to the peccary, and this conclusion could be followed by net avoidance and/or a threat/attack on it. The animal was chased three consecutive times along the entire arena. Besides behavioral records, we also recorded the flight initiation distance and flight speed (details below).

Forced contact test: immediately following the end of the previous test, the handler chased the peccary with the net as described in the previous test; at this time, however, the animal could not flee because both guillotine doors were closed. The test ended when the animal expressed one of the following defensive behaviors: defensive threat/attack on the net or net avoidance followed by flight. In this test, besides the behavioral patterns showed by the animals, we also recorded the flight initiation distance and flight speed.

Foraging/eating in a novel environment test: immediately following the previous test, the keeper left $1.0 \mathrm{~kg}$ of cassava roots (Manihot esculenta), chopped into small pieces, on the test arena floor at the opposite side from where the animal was, opened the guillotine doors, and left the animal free to walk and explore the environment without any aversive stimuli. The cassava root was chosen because it is the favorite food of both peccary species (Nogueira-Filho, personal observation). During this test, which lasted $20 \mathrm{~min}$, besides recording the animals' behaviors, we also determined the feed intake, by the difference between what was offered and the refusal at the end of the experimental session.

After the end of the last test, the individual was restrained again to collect a second blood sample and was then released in its original paddock. The second blood sample was collected to further calculate the change in plasma glucocorticoid concentration after the animals had been through the defense test battery. For this, a second sample of $0.5 \mathrm{~mL}$ of blood was collected from the cephalic veins (see Furtado 2014), stored in sterile plastic tubes containing $0.5 \mathrm{~mL}$ of heparin $(10 \mathrm{U} / \mathrm{mL})$, and kept in a cooler with ice up to the end of the test battery. The samples were centrifuged $\left(1200 \mathrm{~g}, 4^{\circ} \mathrm{C}, 20 \mathrm{~min}\right)$ and plasma was stored at minus $70{ }^{\circ} \mathrm{C}$ until processing at the Núcleo de Pesquisa e Conservação de Cervídeos (NUPECCE)/UNESP, Jaboticabal, São Paulo, Brazil. The glucocorticoid plasma concentration was measured by enzyme immunoassay (Multiskan MS, Labsystem, Helsinki, Finland). The monoclonal cortisol anti-serum (provided by Dr. C. Munro, University of California, Davis, CA, USA) cross-reacted $100 \%$ with cortisol, $9.9 \%$ with prednisolone, $6.3 \%$ with prednisone, $5.0 \%$ with cortisone, and $0.7 \%$ with corticosterone and was validated for the collared peccary by Coradello et al. (2012) and for the white-lipped peccary by Nogueira-Filho et al. (2012).

\section{Data analysis}

The Ethoplayer 1.3 (Leo Software Inc., Toulouse, France) program was used to calculate the time the animals spent 
engaged in all occurrences of the selected behavioral patterns. We chose the exploratory, alert, walk/stop, and lie down patterns to compare the risk assessment between white-lipped and collared peccaries during the first and fourth tests, because they express opposite behavioral trends in the exploration of a new environment against the cautiousness (alert) and avoidance (lie down) reactions. We chose the threat, attack, run away, and jump patterns because they express opposite behavioral trends of confrontation and retreat. In turn, the toothclicking pattern in the four tests was selected because it can be used to express both threatened and cautious behavior by peccaries (Byers and Bekoff 1981; Sowls 1997; NogueiraFilho et al. 1999). Through the recorded images, we also determined the flight initiation distance and flight speed throughout the test battery. We used ink marks every $2.0 \mathrm{~m}$ on the central wall as a reference for distances and a digital chronometer to determine the elapsed time.

In the sequence, we analyzed the data obtained in each test by the principal component analysis (PCA) with the multivariate exploratory technique procedure. Previously, we had standardized the measures by mean-centering them (original variable - mean of original variable)/standard deviation of original variable. This procedure allowed the comparison of variables with different variances due to their different units - for example, the duration of behavioral patterns in seconds and flight speed in $\mathrm{m} / \mathrm{s}$. The factor scores received for each animal in the first principal component (PC1) in each test, which represented the greatest proportion of the data variation (higher eigenvalue), were used to evaluate the discrimination between species (white-lipped and collared peccary) using the $t$ test following Nogueira et al. (2015). To compare the plasma glucocorticoid concentrations, we applied ANOVA with repeated measures for each species, including in the model the effects of the experimental phases (pre- and post-tests) and the sex (male vs. female) as independent factors.

We tested for the effect of pre-test plasma glucocorticoid concentrations on the scores received for each animal in the first principal component-PCA scores - during the novel environment test. We also checked the effect of post-test plasma glucocorticoid concentrations on PCA scores during chase, forced contact, and foraging-eating tests. This was undertaken by running a series of Pearson's correlation analyses between each of the scores and plasma glucocorticoid concentrations. Prior to all analyses, the Lilliefors test was applied to test the normal distribution of data. Logarithmic transformations were used when necessary to meet the assumption of normality. For analyses, we used Statistica 7.0 (StatSoft, Tulsa, OK, USA) and considered the level of significance of $p<0.05$.

\section{Results}

\section{Novel environment test}

The PC1 explained $40.3 \%$ of the variance after the animals entered the novel environment and was bipolar, opposing the exploratory behavior with the cautiousness and avoidance behavioral patterns of lie down and alert (Fig. 1a). The second principal component ( $\mathrm{PC} 2$ ) explained $31.9 \%$ of the variance, along with walk/stop and tooth-clicking patterns, mainly contributing to the upper side of the vertical axis (Fig. 1a).

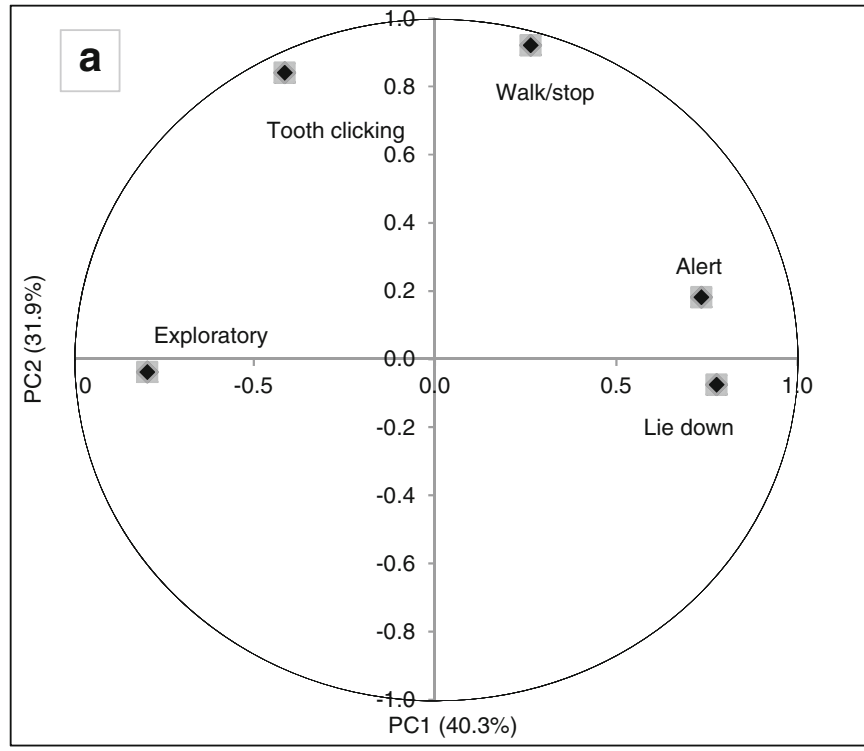

Fig. 1 Results of the principal component analysis applied to novel environment test data. a Loading plot displaying the first and second principal components (PC1 and $\mathrm{PC} 2)$ for the behavioral patterns shown during the novel environment test. b Scores of collared $(N=10)$ and

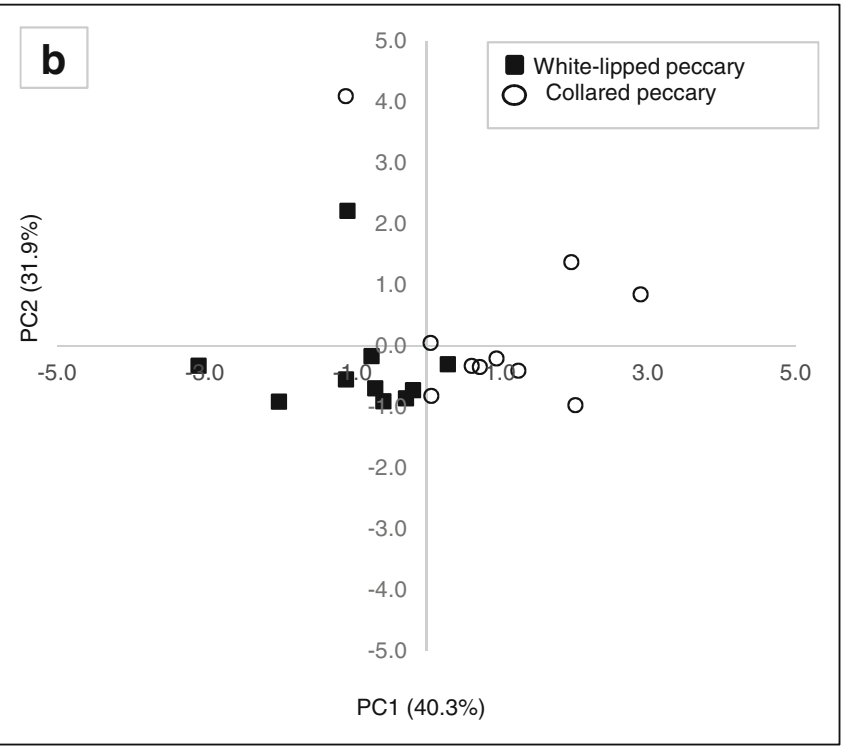

white-lipped $(N=10)$ peccaries in $\mathrm{PC} 1$ and $\mathrm{PC} 2$, where different symbols represent the species. $W L P$ white-lipped peccary, $C P$ collared peccary 
Individuals' scores for both species varied along a continuum of the $x$ axis (PC1; Fig. 1b). There was, however, a clear distinction between the scores obtained by each species in the first novel environment test. The collared peccaries showed higher mean $( \pm \mathrm{SD})$ scores than those of white-lipped peccaries in the first principal component $(0.94 \pm 1.15$ and $-0.94 \pm 0.97$, respectively; $t=3.96 ; p=0.0009)$. The two extremes represented behavioral tendencies; most of the collared peccaries appeared on the right side of the $x$ axis (PC1), which was more correlated to cautiousness (alert) and avoidance (lie down) reactions (Fig. 1a), whereas most of whitelipped peccaries appeared on the left side of the $x$ axis and were more correlated to exploration behavior when facing a new environmental challenge.

\section{Chase test}

The PC1 explained $47.7 \%$ of the data variability and was also bipolar, opposing the threat behavioral pattern, against the running away pattern, flight initiation distance, and flight speed (Fig. 2a). The PC2 explained $20.8 \%$ of the variance, with the tooth-clicking behavioral pattern mainly contributing to the upper side of the $y$ axis (Fig. 2a).

As in the previous test, individuals' scores in both species varied along a continuum of the $x$ axis. Despite this, there was a clear distinction between species in this risk situation test; collared peccaries showed lower mean scores than the whitelipped peccaries in the PC1 scores $(-0.90 \pm 1.40$ and $0.90 \pm 0.59$, respectively; $t=-3.73 ; p=0.001)$. The two extremes also represented behavioral tendencies; all whitelipped peccaries appeared on the right side of the $x$ axis (PC1; Fig. 2b), associating this species with defensive threats/actions against the humans' predator-like cues. In contrast, all collared peccaries appeared on the left side of the $x$ axis and were thus more correlated to the runaway behavioral pattern, along with longer flight initiation distance and higher flight speeds when facing humans' predator-like cues (Fig. 2b).

\section{Forced contact test}

The PC1 explained $44.3 \%$ of the data variability of the forced contact test and was also bipolar, opposing the threat/attack to humans' predator-like cues and tooth-clicking behavioral patterns against the flight initiation distance and flight speed (Fig. 3a). The PC2 explained $23.1 \%$ of the variance with the jump and runaway behavioral patterns, mainly contributing to the bottom side of the $y$ axis (Fig. 3a).

In the second risk situation test, there was also a clear distinction between species in the PC1 scores; the collared peccaries showed lower mean scores than the white-lipped peccaries $(-1.52 \pm 0.52$ and $1.52 \pm 1.07$, respectively; $t=-8.07 ; p<0.00001)$. All white-lipped peccaries appeared on the right of the $x$ axis (PC1; Fig. 3b) and were more correlated with the threat/attack pattern as well as with the toothclicking act, while all collared peccaries appeared on the left side of the same axis, more correlated, therefore, with longer flight initiation distances and higher flight speeds when facing humans' predator-like cues. Moreover, one collared peccary is shown at the bottom side of the $y$ axis (PC2; Fig. 3b) and was correlated with the jump and runaway patterns.

\section{Foraging/eating in a novel environment test}

The PC1 explained $38.1 \%$ of the data variability when the peccaries were foraging and eating food in a new condition and immediately after the chase tests. As in the previous tests,

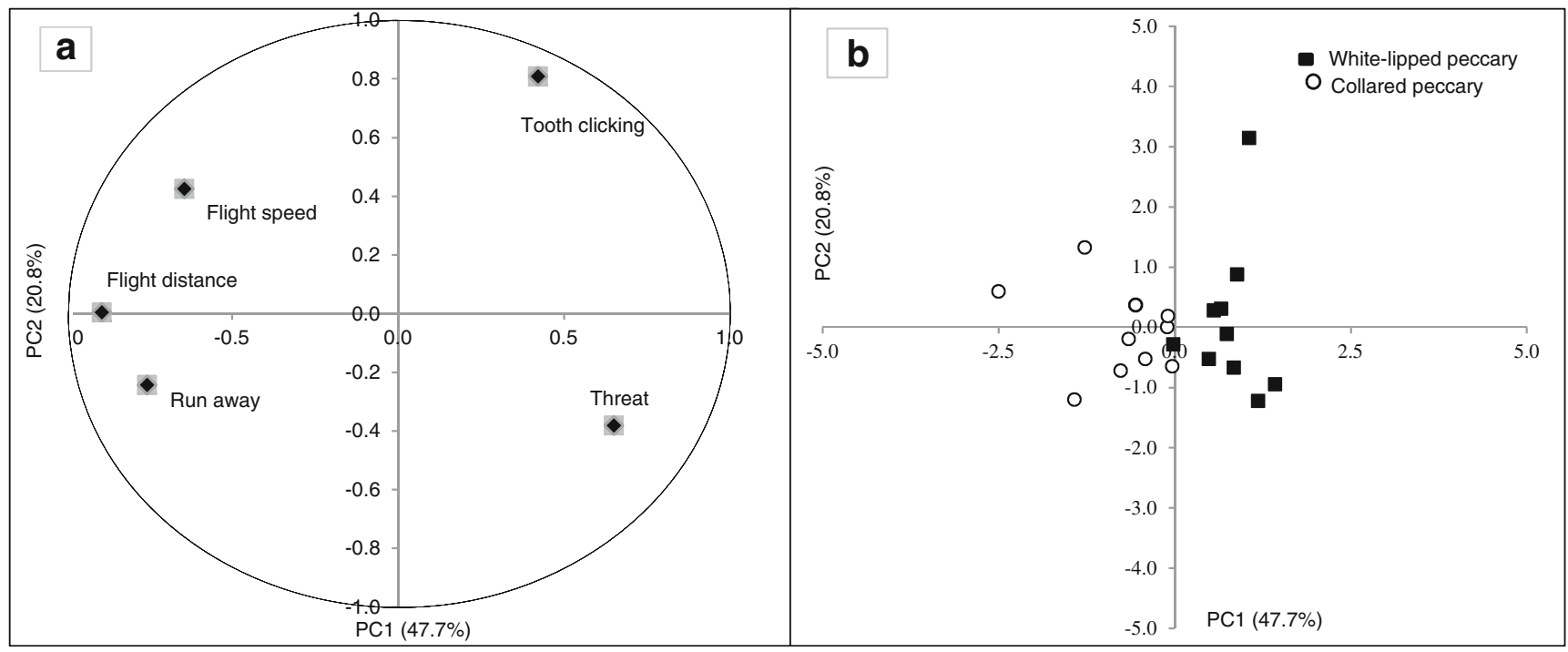

Fig. 2 Results of the principal component analysis applied to chase test data. a Loading plot displaying the first and second principal components (PC1 and PC2) for the behavioral patterns, flight initiation distance, and

flight speed shown during the chase test. b Scores of collared $(N=10)$ and white-lipped $(N=10)$ peccaries in $\mathrm{PC} 1$ and $\mathrm{PC} 2$, where different symbols represent the species. $W L P$ white-lipped peccary, $C P$ collared peccary 


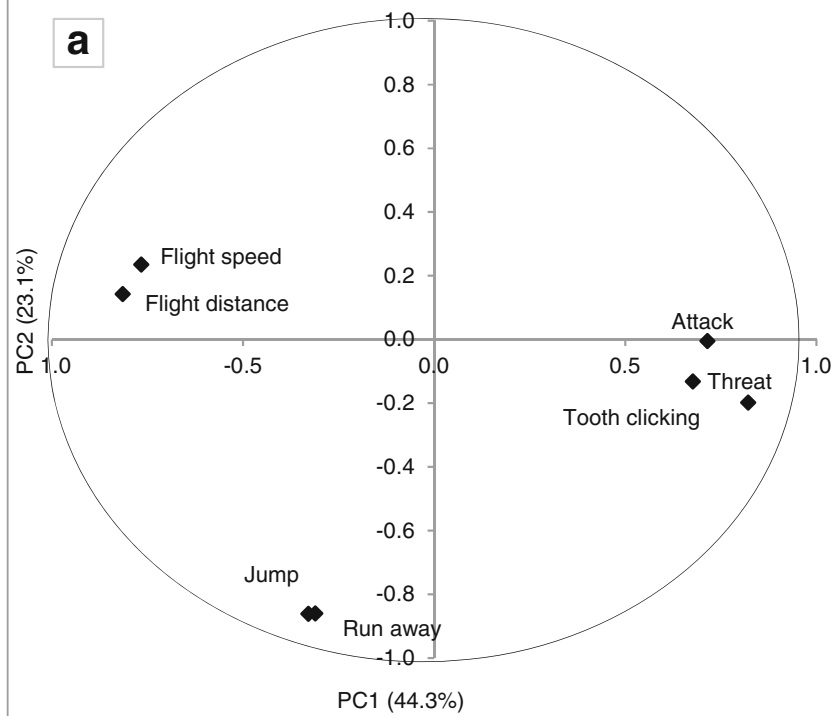

Fig. 3 Results of the principal component analysis applied to forced contact test data. a Loading plot displaying the first and second principal components (PC1 and $\mathrm{PC} 2$ ) for the behavioral patterns, flight initiation distance, and flight speed shown during the forced contact test.

the PC1 was also bipolar, opposing the exploratory behavioral pattern and food intake with the lie down avoidance pattern (Fig. 4a). The PC2 explained $26.7 \%$ of the variance and was also bipolar, opposing the tooth clicking with the alert and walk/stop actions, associated with cautiousness and avoidance behavioral patterns, mainly contributing to the bottom side of the $y$ axis (PC2; Fig. 4a).

As in all previous tests, it was possible to differentiate the species in the PC1 scores, and the collared peccaries showed higher values than the white-lipped peccaries $(1.32 \pm 0.58$ and $-1.32 \pm 0.76$, respectively; $t=8.72 ; p<0.0001)$. The individuals' scores in both species varied along a continuum of the $x$ axis and the two extremes representing behavioral tendencies; all collared peccaries appeared on the right side of the $x$ axis (PC1; Fig. 4b), more correlated to the avoidance lie down pattern. All white-lipped peccaries, in contrast, appeared on the left side of the $x$ axis and were more correlated, thus, with the exploratory behavior in a new environment, even after facing the situations involving two humans' predator-like cues. Furthermore, 6 out of 10 white-lipped peccaries ate the cassava roots, while none of the collared peccaries fed.

\section{Correlations between tests}

There were positive correlations between the scores received for each animal within both novel condition tests $\left(r_{\text {Pearson }}=0.64, p<0.05\right)$ and both humans' predator-like cues (chase and forced contact tests) $\left(r_{\text {Pearson }}=0.67, p<0.05\right)$. We also found that peccaries with a high degree of exploration also showed more viciousness towards the capture net, as there was a negative correlation between the scores received

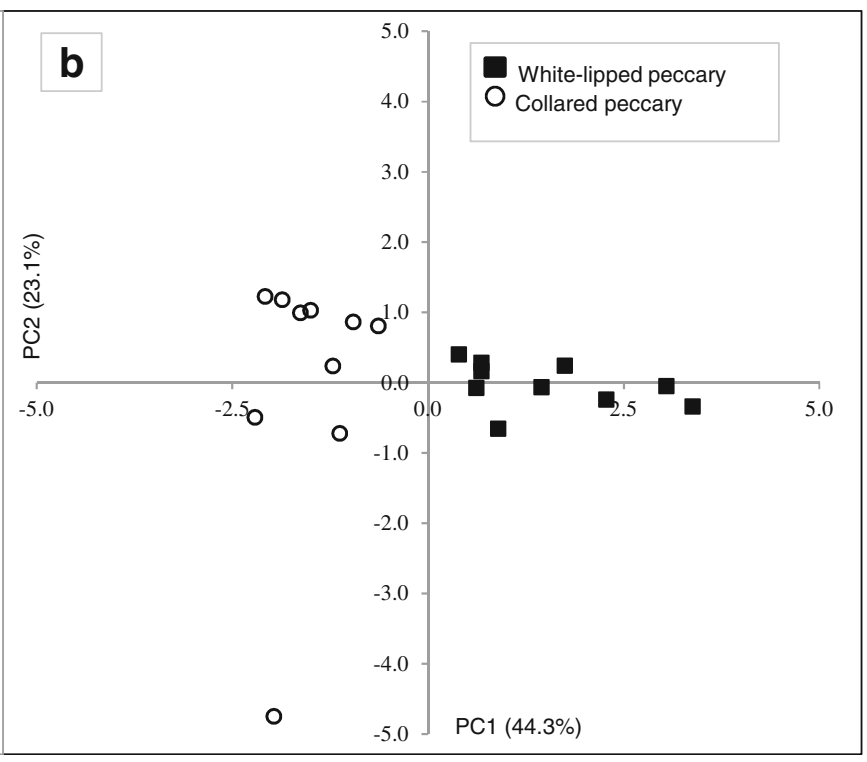

b Scores of collared $(N=10)$ and white-lipped $(N=10)$ peccaries in PC1 and PC2, where different symbols represent the species. WLP whitelipped peccary, $C P$ collared peccary

for each animal between both novel condition and humans' predator-like cues during chase and forced contact tests (Table 1).

\section{Plasma glucocorticoid concentration and its effects on behavior}

The average ( $\pm \mathrm{SD}$ ) levels of plasma glucocorticoid concentration differed between conditions (pre- and post-tests) for collared peccary $(F=45.19, p=0.0001)$ and white-lipped peccary $(F=49.55, p=0.0001)$ (Fig. 5). The statistical model, however, did not show a difference between males and females of collared peccary $(F=3.98, p=0.09)$ and whitelipped peccary $(F=0.03, p=0.95)$. There was also no interaction between sex and conditions (pre- and post-tests) for collared peccary $(F=0.18, p=0.68)$ and white-lipped peccary $(F=0.19, p=0.67)$.

We verified a correlation between pre-test plasma glucocorticoid concentrations and PCA scores during the novel environment test $(=0.89, p=0.0001, N=10)$. The same was not verified for white-lipped peccaries $(r=0.07, p=0.85, N=10)$. We also verified a negative correlation between post-test plasma glucocorticoid concentrations and PCA scores during the forced contact test $(r=-0.69, p=0.02, N=10)$. In contrast, for white-lipped peccaries, we verified just a trend of positive correlation between post-test plasma glucocorticoid concentrations and PCA scores during the forced contact test $(r=-0.62, p=0.06, N=10)$. Post-test plasma glucocorticoid concentration was not correlated with PCA scores during the chase test and during the foraging/eating in a novel environment test for both species. 


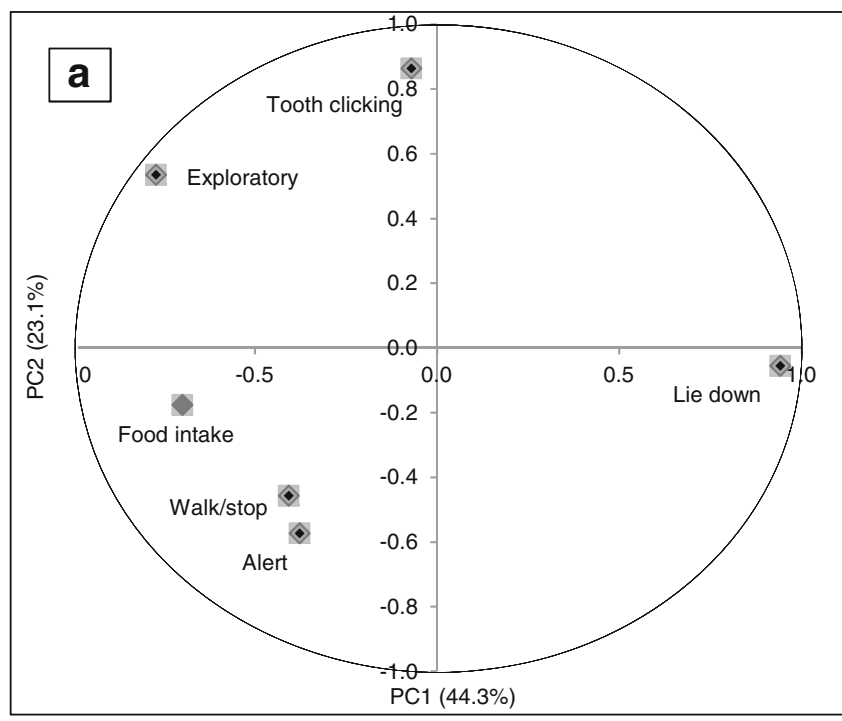

Fig. 4 Results of the principal component analysis applied to foraging/ eating in a novel environment test data. a Loading plot displaying the first and second principal components (PC1 and $\mathrm{PC} 2$ ) for the behavioral patterns shown during the foraging/eating in a novel environment test.

\section{Discussion}

The adapted MDTB paradigm (Blanchard et al. 2003) allowed assessment of the defensive behavioral patterns of whitelipped and collared peccaries. Although both species show similar behavioral patterns during risk situation challenges, such as alertness, threat, and attack, we found that they differed in the intensity of these reactions, showing plasticity differences between species. For example, when facing novel environment, most of white-lipped peccaries displayed behavioral patterns that challenged risks and were more exploratory and chasing, whereas most of collared peccaries showed more cautious patterns. Facing risk challenges with humans' predator-like cues, during chase and forced contact tests, most white-lipped peccaries threatened the capture net and some of them attacked it when cornered. Facing the same risk situation, collared peccaries often just jumped away from the net, running away from the source of the menace, and although some of them threatened the capture net, they never attacked it. Moreover, the effects of acute stress, verified by the significant increase in glucocorticoid concentrations between pre-

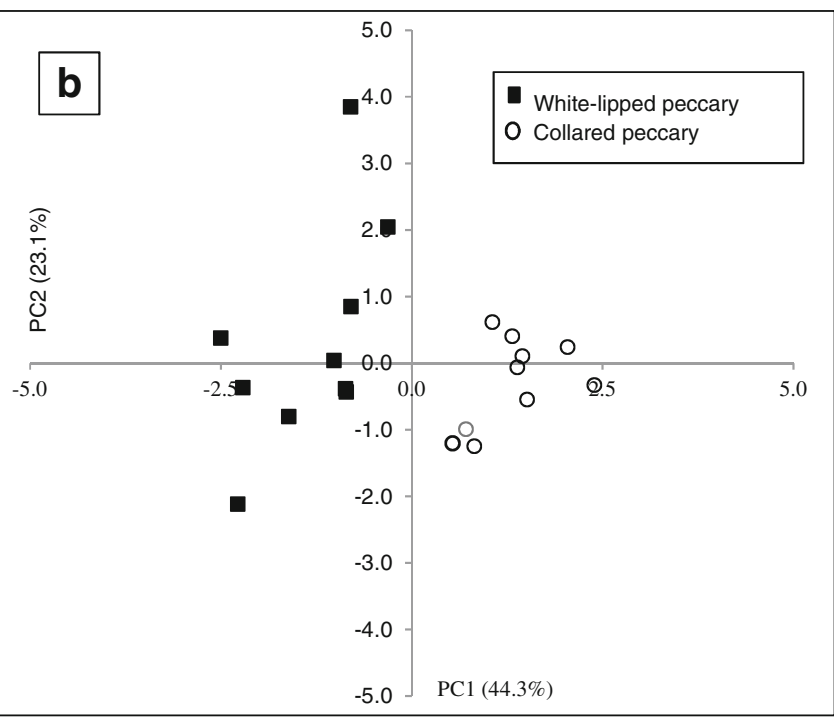

b Scores of collared $(N=10)$ and white-lipped $(N=10)$ peccaries in PC1 and $\mathrm{PC} 2$, where different symbols represent the species. WLP whitelipped peccary, $C P$ collared peccary

and post-tests in both species, showed a relationship between the hormone and some behavioral responses.

Neophilia, promoting exploration, is a trait directly related to behavioral plasticity (Mason et al. 2013; Sih 2013). This behavioral plasticity trait, expressed by the behavioral trend of white-lipped peccaries to explore the new environment recorded here, was also reported for free-ranging groups that walked an average of $10 \mathrm{~km}$ per day, expanding their home range according to food availability (Fragoso 1998). The species adopts movement patterns that resemble nomadic behavior, exploring their habitats in search of food (Jácomo 2013). The collared peccary groups, in contrast, are territorial and use comparatively smaller home ranges than white-lipped peccary (Kiltie and Terborgh 1983; Fragoso 1998; Keuroghlian et al. 2004). Surprisingly, the risk-aversive trend behavior exhibited by the collared peccary in our first test is not in agreement with the available literature, which reported that this species is more widely distributed in comparison to the white-lipped peccary (Sowls 1997; Taber et al. 2011). This apparently controversial result can probably be explained by Dingemanse and Réale's (2005) review. These authors concluded that in
Table 1 Pearson's correlation matrix between scores received in the first principal component (PC1) of collared $(N=10)$ and white-lipped $(N=10)$ peccaries in each one of the defense battery tests: novel environment, chase, forced contact, and foraging/ eating novel environment

\begin{tabular}{lllll}
\hline Test & Novel environment & Foraging/eating & Chase & Forced contact \\
\hline Novel environment & - & & & \\
Foraging/eating novel environment & $0.64^{*}$ & - & & \\
Chase test & $-0.66^{*}$ & $-0.60^{*}$ & - & \\
Forced contact & $-0.71^{*}$ & $-0.81^{*}$ & $0.67^{*}$ & - \\
\hline
\end{tabular}

*Marked correlations are significant at $p<0.05$ 
Fig. 5 The average $( \pm \mathrm{SD})$ plasma glucocorticoid concentration $(\mu \mathrm{g} / \mathrm{dL})$ between conditions (pre- and post-tests) for collared peccary $(N=10)$ and white-lipped peccary $(N=10)$

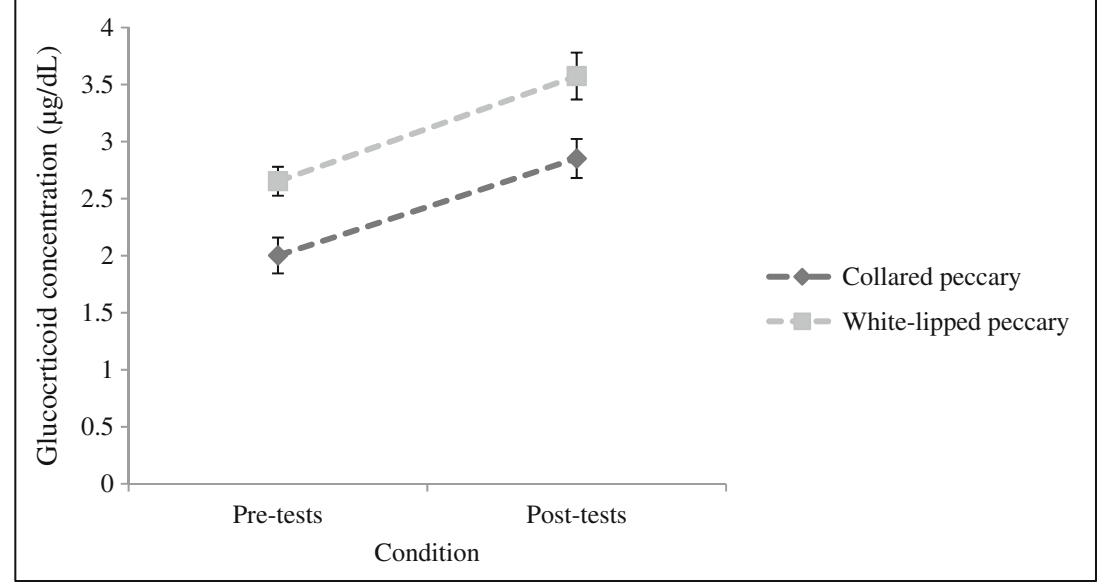

changeable environments, more exploratory, active, or aggressive animals are less successful over multiple years than less exploratory, less active, and passive types. Then, the apparently low level of behavioral plasticity has favored the collared peccary, allowing it to thrive when faced with HIREC challenges, such as habitat loss and human harvesting.

The boldness shown by most of the white-lipped peccaries in our study is another trait related to behavioral plasticity that usually allows a species to cope with new stimuli, resources, or dangers (Mason et al. 2013; Sih 2013). Free-ranging, whitelipped peccaries are known for their use of the mass attack strategy against predators (Sowls 1997; Taber et al. 2011). Moreover, white-lipped peccaries showed shorter flight initiation distances and lower flight speeds, revealing more confidence in the presence of the capture net, compared to collared peccaries facing humans' predator-like cues. Kiltie (1980) observed similar differences between the species when they moved away from a menace in natural conditions. This author reports that when he approached the free-ranging groups, collared peccaries usually fled almost immediately, while the individuals of white-lipped peccary herds moved out slowly, probably because white-lipped peccaries' strength is in numbers. Kiltie and Terborgh (1983) suggested that predation is possibly the main evolutionary force that leads the whitelipped peccary to live in huge herds of more than a hundred individuals. Although free-ranging animals have less opportunity to learn to face predation in natural conditions, different levels of predation or potential risk to which prey is submitted are responsible for causing changes to their anti-predatory behavior (e.g., Brown et al. 2006). Through this learning process, wild animals can assess at least some predation risks in the environment and adjust behaviors in an attempt to reduce those risks (Martin 2011). The various defensive abilities developed throughout the evolutionary history of each species can dictate the level of success for animal populations (Blanchard et al. 2001). Indeed, the white-lipped peccary strategy of counterattacking was apparently efficient in dealing with their natural predators, optimizing survival. Facing increased levels of habitat loss and human harvesting, the white-lipped peccary's viciousness against human opponents suggests impairment in the species' risk assessment abilities (see Caro 2005; Sih 2013). This probably happens because differences in defensive strategies adopted by prey also elicit different responses from their predators (Blanchard et al. 2001), which can be observed in the behavior of peccary hunters. While collared peccaries are more often killed by lone hunters, white-lipped peccaries are more pursued by groups of hunters, when living in large groups (Sowls 1997). As a result, up to 25 white-lipped peccaries are killed at a time (Sowls 1997).

The behavioral variations within peccary populations, shown by the PCA scores in our study, varying along a continuum for both species, may address a hypothesis that hunting pressure is selecting more cautious individuals. Dall et al. (2004) pointed out that behavioral diversity may influence the population's responses to environmental changes. This proposition corroborates the information that even in heavily hunted areas, some white-lipped peccary individuals persist (Fragoso, personal communication). Moreover, free-ranging animals simultaneously face multiple stressors, and the decline in species is often caused by the combined negative impacts of these multiple stressors (Sih 2013). However, our study highlights the possibility that different responses from peccaries to human harvesting may be one of these stressors. To validate our hypothesis, however, further studies need to be carried out in the wild to provide the ecological context required to evaluate the potential evolutionary significance variation of such trends (Blumstein et al. 2010).

The endocrine response to the acute stress caused by challenges during the successive tests triggered some behavioral changes. For example, the higher the pre-test plasma glucocorticoid concentrations were, the more collared peccaries stayed alert and remained in the lie down pattern during the novel environment test. The higher the post-test plasma glucocorticoid levels were, the more white-lipped peccaries showed threat, attack, and tooth-clicking patterns against the 
capture net during the forced contact test. Apparently, acute stress also affected the feeding behavior of collared peccaries, whereas most white-lipped peccaries ate cassava roots offered during the last test. However, we verified no correlation for both species between endocrine and behavioral responses during the foraging/eating in a novel environment test. The average concentration of plasma glucocorticoids determined in the pre-test samples was similar to the ones previously determined for the collared peccary (Hughes and Lytle 1975; MontesPerez et al. 2012). Unfortunately, there is no information on this measure for the white-lipped peccary. The species' behavioral trend differences - exploration for the white-lipped peccary and cautiousness for the collared peccary-apparently reflect the tolerance of the white-lipped peccary to high levels of stress without feeding avoidance, which can be related to divergences in the species' physiology mechanisms, driving variation at the behavioral level. The lack of differences between sexes in plasma glucocorticoid concentrations in both species can likely be explained by the low sample size used in this study.

Clearly, behavioral differences between white-lipped and collared peccaries are just one of the factors, but certainly not the only one, that affect their conservation status. As in the example of habitat fragmentation, the collared peccary is less affected than the white-lipped peccary and can maintain healthy populations even in highly degraded areas due to differences in ecological requirements between the two species (Cullen et al. 2001; Peres 2001; Taber et al. 2016). The collared peccary usually lives in herds of 10 animals, but the herd size can vary widely from 6 to over 30 individuals, depending on habitat (Taber et al. 2011). This species also occupies smaller home ranges than white-lipped peccary (Kiltie and Terborgh 1983; Fragoso 1998; Keuroghlian et al. 2004). Thus, its small-range requirements may facilitate its survival in disturbed forest remnants (Gongora et al. 2011) and may allow the gradual colonization of new available habitats. In turn, white-lipped peccary herd sizes vary from 10 to over 300 individuals according to different ecological and human conditions they are subjected (Reyna-Hurtado et al. 2016), with historical accounts of groups of over 1000 animals (Taber et al. 2011), which require extensive and contiguous areas of habitat to obtain sufficient resources throughout the year (Keuroghlian et al. 2013; Keuroghlian et al. 2015).

In conclusion, the behavioral correlations through the tests, as well as the relationship with endocrine and behavioral responses, showed that the MDTB, adapted from Blanchard et al. (2003), allowed us to record differences in the defensive behavior patterns of the white-lipped and collared peccaries. As expected, the white-lipped peccary did show higher exploration in the new environment (i.e., test arena) than the collared peccary. Furthermore, when subjected to humans' predator-like cues, most white-lipped peccaries showed defensive threat and attack behavioral patterns, while collared peccaries usually showed more alertness and avoidance/ retreat patterns. The differences in behavioral plasticity between white-lipped and collared peccaries reported here yield new insights for understanding variation in behavioral response and mechanisms involved when these species face HIREC in their natural environments, as proposed by Mason et al. (2013). The white-lipped peccary's exploration and predator threat and attack patterns might expose the species to unnecessary risks, leading to higher mortality compared to the cautious patterns of the collared peccary, when facing increasing levels of human harvesting. Our study presented evidence that different behavioral response from peccaries to human harvesting needs to be taken into account as an important factor, together with many other simultaneous factors, contributing to white-lipped peccary decline. Despite the experimental difficulties in validating this hypothesis in natural conditions, further studies need to be done to evaluate this information in the wild.

Acknowledgements We are extremely grateful to Michele Devi Singh and to anonymous reviewers for their comments on the manuscript and English review. We are also grateful to all the staff of the Applied Ethology Laboratory, Universidade Estadual de Santa Cruz. This study was under the auspices of the Coordenação de Aperfeiçoamento de Pessoal de Nível Superior (CAPES/PROCAD-NF \#794-2009) and UESC. Selene S.C. Nogueira and Sérgio L.G. Nogueira-Filho were supported by the Conselho Nacional de Desenvolvimento Científico e Tecnológico (CNPq Processes 303743/2013-1 and \#303589/2015-9), respectively. Aline M. Reis and Stefane G. Marsaro were supported by the CAPES and the Fundação de Amparo à Pesquisa do Estado da Bahia (FAPESB), respectively.

\section{References}

Baldwin MJ (1896) A new factor in evolution. Amer Nat 30:441-451

Beck H, Thebpanya P, Filiaggi M (2010) Do Neotropical peccary species (Tayassuidae) function as ecosystem engineers for anurans? J Trop Ecol 26:407-414

Beckerman AP, Wieski K, Baird DJ (2007) Behavioural versus physiological mediation of life history under predation risk. Oecologia 152: 335-343

Blanchard RJ, Blanchard DC (1988) Ethoexperimental approaches to the biology of emotion. Annu Rev Psychol 39:43-68

Blanchard RJ, Yang M, Li C, Gervacio A, Blanchard DC (2001) Cue and context conditioning of defensive behaviors to cat odor stimuli. Neurosci Biobehav R 25:587-595

Blanchard DC, Griebel G, Blanchard RJ (2003) The mouse defense test battery: pharmacological and behavioral assays for anxiety and panic. Eur J Pharmacol 463:97-116

Blumstein DT, Ebensperger LA, Hayes LD, Vásquez RA, Ahern TH, Burger JR et al (2010) Towards an integrative understanding of social behavior: new models and new opportunities. Front Behav Neurosci 4:1-9

Brown GE, Rive-Maud AC, Ferrari CO, Chivers DP (2006) The dynamic nature of antipredator behavior: prey fish integrate threat-sensitive antipredator responses within background levels of predation risk. Behav Ecol Sociobiol 61:9-16

Byers JA, Bekoff M (1981) Social, spacing and cooperative behavior of collared peccary. J Mammal 62:767-785 
Cabassu Y (2010) Impacts of indigenous subsistence hunting on wildlife abundance in the Rio Platano Biosphere Reserve, Honduras. M.Sc. thesis, Carleton University.

Caro T (2005). Antipredator defense in birds and mammals. University of Chicago press, Chicago

Charmantier A, McCleery RH, Cole LR, Perrins C, Kruuk LEB, Sheldon BC (2008) Adaptive phenotypic plasticity in response to climate change in a wild bird population. Science 320:800-803

Cockrem JF (2013) Corticosterone responses and personality in birds: individual variation and the ability to cope with environmental changes due to climate change. Gen Comp Endocrinol 190:156-163

Coradello MA, Morais RN, Roper J, Spercoski KM, Massuda T, Nogueira SSC, Nogueira-Filho SLG (2012) Validation of a fecal glucocorticoid metabolite assay for collared peccaries (Pecari tajacu). J Zoo Wildlife Med 43:69-76

Cullen L, Bodmer ER, Valladares-Padua C (2001) Ecological consequences of hunting in Atlantic forest patches, São Paulo, Brazil. Oryx 35:137-144

Dall SRX, Houston AI, McNamara JM (2004) The behavioural ecology of personality: consistent individual differences from an adaptive perspective. Ecol Lett 7:734-739 doi:10.1111/j.1461-0248.2004.00618.x

Desbiez ALJ, Santos SA, Keuroghlian A, Bodmer RE (2009) Niche partitioning among white-lipped peccaries (Tayassu pecari), collared peccaries (Pecari tajacu), and feral pigs (Sus scrofa). J Mammal 90:119-128

Dielenberg RA, McGregor IS (2001) Defensive behavior in rats towards predatory odors: a review. Neurosci Biobehav Rev 25:597-609

Fragoso JMV (1998) Home range and movement patterns of white-lipped peccary (Tayassu pecari) herds in the northern Brazilian amazon. Biotropica 30:458-469

Gongora J, Reyna-Hurtado R, Beck H, Taber A, Altrichter M and Keuroghlian A. 2011. Pecari tajacu. n: IUCN 2012. IUCN List of Threatened Species. doi: 10.2305/IUCN.UK.2011-2.RLTS. T41777A10562361.en Accessed 10 Feb 2016

Herborn KA, Heidinger BJ, Alexander L, Arnold KE (2014) Personality predicts behavioural flexibility in a fluctuating, natural environment. Behav Ecol 25:1374-1379

Hughes JP, Lytle IM (1975) Corticosteroids of the peccary (Dicotyles tajacu). Gen Comp Endocr 26:277-280

Kavaliers M, Choleris E (2001) Antipredator responses and defensive behavior: ecological and ethological approaches for the neurosciences. Neurosci Biobehav R 25:577-586

Keuroghlian A, Eaton DP, Longland WS (2004) Area use by white-lipped and collared peccaries (Tayassu pecari and Tayassu tajacu) in a tropical forest fragment. Biol Conserv 120:421-425

Keuroghlian A, Desbiez A, Reyna-Hurtado R, Altrichter M, Beck H, Taber A, Fragoso, JMV (2013) Tayassu pecari. In: IUCN 2013. IUCN Red List of Threatened Species. doi: 10.2305/IUCN.UK. 2013-1.RLTS.T41778A44051115.en Accessed 10 Feb 2016

Keuroghlian A, Santos MCA, Eaton DP (2015) The effects of deforestation on white-lipped peccary (Tayassu pecari) home range in the southern Pantanal. Mammalia 70:491-497

Kiltie RA (1980) Seed predation and group size in rain forest peccaries. Dissertation, Princeton University

Kiltie RA, Terborgh J (1983) Observations on the behavior of rain forest peccaries in Peru: why do white-lipped peccaries form herds. Zeit Tierpsychology 62:241-255

Licona M, McCleery R, Collier B, Brightsmith DJ, Lopez R (2011) Using ungulate occurrence to evaluate community-based conservation within a biosphere reserve model. Anim Conserv 14:206-214

Lima SL, Dill LM (1990) Behavioral decisions made under the risk of predation: a review and prospectus. Can J Zoo 68:619-640

Luttbeg B, Sih A (2010) Risk, resources and state- dependent adaptive behavioural syndromes. Roy Soc Lond B Bio 365:3977-3990

Martin, TE (2011) The cost of fear. Science 34:1353-1354
Mason GJ (2010) Species differences in responses to captivity: stress, welfare and the comparative method. Trends Ecol Evol 25:713-721

Mason GJ, Burn CC, Dallaire JA, Kroshko J, Kinkaid HM et al (2013) Plastic animals in cages: behavioural flexibility and responses to captivity. Anim Behav 85:1113-1126

Montes-Perez RC, Kuri-Melo L, Mukul-Yerves JM, Segura-Correa JC, Centurión Castro FG (2012) Effects of two space allowances on cortisol levels, agonistic behavior and their relationship with the ovarian cycle of the collared peccary (Pecari tajacu) in captivity. Arch Latinoam Prod Anim 20:77-83

Nersesian CL, Banks PB, McArthur C (2012) Behavioural responses to indirect and direct predator cues by a mammalian herbivore, the common brushtail possum. Behav Ecol Sociobiol 66:47-55

Nogueira SSC, Macedo J, Sant' Anna A, Nogueira-Filho SLG, da Costa MJR P (2015) Assessment of temperament traits of white-lipped (Tayassu pecari) and collared peccaries (Pecari tajacu) during handling in a farmed environment. Anim Welf 24:291-298

Nogueira-Filho SLG, Nogueira SSC, Sato T (1999) A estrutura social de pecaris (Mammalia, Tayassuidae) em cativeiro. Rev Etol 1:89-98

Nogueira-Filho SLG, Carvalho H, Peregrino H, Fernandes LC, Nogueira SSC (2012) Stress assessment in white-lipped peccaries (Tayassu pecari). Suiform Soundings 11:21-28

Orrock J, Danielson B, Brinkerhoff R (2004) Rodent foraging is affected by indirect, but not by direct, cues of predation risk. Behav Ecol 15:433-437

Peres AC (2001) Synergistic effects of subsistence hunting and habitat fragmentation on Amazon forest vertebrates. Conserv Biol 15:1490-1505

Price TD, Qvarnström A, Irwin DE (2003) The role of phenotypic plasticity in driving genetic evolution. Proc R Soc Lond B Biol Sci 270: $1433-1440$

Reyna-Hurtado R, Beck H, Altrichter M, Chapman CA, Bonnell TR et al (2016) What ecological and anthropogenic factors affect group size in white-lipped peccaries (Tayassu pecari)? Biotropica 48:246-254

Ribeiro-Barbosa ER, Canteras NS, Cezário AF, Blanchard RJ, Blanchard DC (2005) An alternative experimental procedure for studying predatorrelated defensive responses. Neurosci Biobehav R 29:1255-1263

Schmidt KA (2006) Non-additivity among multiple cues of predation risk: a behaviorally-driven trophic cascade between owls and songbirds. Oikos 113:82-90

Sih A (2013) Understanding variation in behavioural responses to human-induced rapid environmental change: a conceptual overview. Anim Behav 85:1077-1088

Sih A, Ferrari MCO, Harris DJ (2011) Evolution and behavioural responses to human-induced rapid environmental change. Evol Appl 4:367-387

Sowls, LK (1997). Javelinas and other peccaries: their biology, management and use. 2 ed. Texas A\&M University Press, Arizona

Taber A, Altrichter M, Beck H, Gongora J (2011) The Tayassuidae. In: Wilson DE, Mittermeier RA (eds) Handbook of the mammals of the world: hoofed mammals, vol 2. Lynx Edicions, Barcelona, pp 292-307

Taber A, Beck H, Gonzalez S, Altrichter M, Duarta JMB, Reyna-Hurtado R (2016) Why Neotropical forest ungulates matter. In: Aguirre AA, Sukumar R (eds) Tropical conservation: perspectives on local and global priorities. Oxford University Press, Oxford, pp 255-261

Ticktin T (2003) Relationships between El Niño-Southern Oscillations and demographic patterns in a substitute food for collared peccaries in Panama. Biotropica 35:189-197

van Buskirk J (2012) Behavioural plasticity and environmental change. In: Candolin U, Wong BBM (eds) Behavioural responses to a changing world: mechanisms and consequences. Oxford University Press, Oxford, pp 145-158

Wingfield JC (2013) Biology of environmental stress: behavioral endocrinology and variation in the ability to cope with novel environments. Anim Behav 85:1127-1133

Wolf M, Van Doorn GS, Leimar O, Weissing FJ (2007) Life-history trade-offs favour the evolution of animal personalities. Nature 447: 581-584 